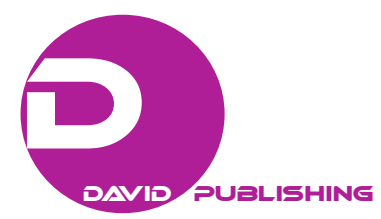

\title{
Use and Abuse of Privileged Information in Italian Listed Companies
}

\author{
Annalisa Baldissera \\ University of Brescia, Brescia, Italy
}

\begin{abstract}
Privileged information has significant importance to listed companies, given both the extent of the markets in which it is used and the relevant effects that it can produce on the prices of financial instruments. The term "privileged information” means information that has not yet been made known to the public, which, if disclosed, is able to affect significantly the prices of the securities of listed issuers. This article aims to prove that in many cases, the effects of privileged information can be adequately represented in financial statements, despite their "confidential” nature. For this purpose, this research proposes the existence of a relationship—which can be virtuous or vicious—between financial statements and privileged information. In order to demonstate this thesis, the author carried out an empirical survey concerning both the economic and the legal sector. For the first one, the research considered the price-sensitive information published by companies listed on the Italian Stock Exchange during the first half of 2018, and the result shows that a lot of privileged information is able to generate accounting effects; for the second one, the empirical survey analyzed some significant judgments passed by the Italian Court of Cassation in the 2000s which confirm the companies' violation of the duty to present privileged information in financial statements.
\end{abstract}

Keywords: privileged information, financial statements, listed companies

\section{Introduction and Research Aims}

Interest in privileged information, and more generally in market abuse, dates back, overseas, to at least the beginning of the 1930s (Austin, 2017; Gaillard, 1992; Markham, 2002), following the crisis of 1929, and is developing in the European Union (Bagley, 2017) more than 50 years later on the basis of the regulation contained in the first Directive on the subject (the 89/592/EEC), implemented in Italy with Law 157/1991.

Since then, intense legal activity_European and national ${ }^{1}$ — has been carried out, aimed at ensuring the efficiency of the financial markets and protecting savers through a detailed identification of the market abuse cases, the implementation of a systems of controls and sanctions, and the establishment of a supervisory body belonging to the European jurisdiction (ESFS). ${ }^{2}$

This paper focuses in particular on the privileged "price-sensitive” information published by Italian listed issuers.

Annalisa Baldissera, Ph.D., assistant professor, Department of Law, University of Brescia, Brescia, Italy.

Correspondence concerning this article should be addressed to Annalisa Baldissera, Via San Faustino No. 41, Brescia 25122, Italy.

1 Some of the main ones are Legislative Decree 58/1998 (Italian Consolidate Law on Finance) (primary national legislation), Directive 2003/6/EC (MAD), Directive 2003/124/EC, Directive 2003/125/EC, Directive 2004/72/EC, Directive 2004/39/EC (MIFID 1), Regulation (EU) 596/2014 (MAR), Directive 2014/57/EU (MAD II), and Directive 2014/65/EU (MIFID 2).

2 European System of Financial Supervisors. 
The aim of this study is to demonstrate that privileged information presents systematic and non-random links with the financial statements.

For this purpose, the research is structured as follows.

(1) The formulation of hypotheses, and, in particular, the subdivision of privileged information in two main groups, depending on whether or not the information can be represented in the financial statements.

(2) The conduct of two empirical researches to verify the correctness of the thesis:

(a) the reconstruction of the privileged information published by the companies listed on the Italian Stock Exchange;

(b) the case-law survey.

(3) The statement of the thesis according to which when the privileged information can be represented in the financial statements and this does not occur, the non-confidential information becomes confidential precisely because of its accounting omission.

(4) The confirmation that the financial statements can perform, with respect to privileged information, both a physiological function of disclosure and a pathological function of concealment.

\section{The Theoretical Framework}

The international literature concerning privileged information is particularly wide and differs, in many respects, from the national one.

In particular, four major strands of studies can be identified:

(a) legal studies;

(b) accounting studies;

(c) business ethics studies;

(d) market studies.

With regard to the very extensive legal studies under letter (a), the subject of privileged information rarely forms an object of independent investigation, being more widely studied in close connection with insider dealing, market manipulation, and market abuse, especially because of the similarity of the sanctioning system:

An insider is defined to include members of management and boards of directors, persons holding ten percent of the shares of a company (directly or through related parties) or someone who due to his profession, activities, duties or relations of connection of a trade company has access to privileged information. Insider trading and market manipulation are subject only to civil sanctions and do not carry criminal liability. (Ali \& Gregoriou, 2009, p. 81)

Within this area, legal investigations (Davies, Hopt, Nowak, \& Van Solinge, 2013; Friedrichs, 2009; Stamp \& Welsh, 1996; Tricker, 2015) and studies of comparative law (Gaillard, 1992; Loke, 2006; Veil, 2017) can be included, given their common interest in the consequences of the globalization of financial markets.

As for the accounting studies under letter (b) (Bailey, Li, Mao, \& Zhong, 2003; Leuz \& Wüstemann, 2003; Wüstemann, 2003), it should be noted that the problem of relationships between financial statements and privileged information is less treated, given that the main investigations tend to focus on the cases of crimes that occur when, regardless of the accounting representation, the information is intentionally used to manipulate the market.

However, it is probable that this scientific attitude—only slightly attracted by the problem—is determined by the hypothesis (or the acknowledgment) that, given the possibility of manipulating accounting values, and in particular the evaluation criteria, their importance to financial market choices is not always decisive: 


\begin{abstract}
Shareholders are entitled to the residual real or physical capital of the firm. Valuation rules translate this entitlement into units of money, say dollars. All valuation rules are imperfect and vulnerable to manipulation. Fortunately, the choice of a valuation rule affects only one of the five functions of accounting. The data provided for the functioning of equity markets are based largely on valuation rules. The other four functions of accounting (measurement of inputs, determination of entitlements, contract performance, and provision of the common knowledge base) are largely independent of the valuation rules chosen to prepare financial statements. Valuation rules play no role in measuring inputs of agents because these are measured in physical units, nor do they determine the entitlement of any agent, except, partly, the top managers. (Sunder, 1997, pp. 97-98)
\end{abstract}

As regards the business ethics studies under letter (c), it is important to note the peculiar attitude that a part of the doctrine assumes towards the defense of privileged information, the privileged information being understood not only as an instrument to prevent market abuses but also as an object that, if legitimately possessed, is worthy of legal protection (Allhoff \& Vaidya, 2005; Bainbridge, 2013; Boonin \& Oddie, 2005; Caprio, 2013; Easterbrook, 1981; Sekhar, 2002).

Privileged information is to be protected for many reasons: (1) for moral purposes, given that "no one should profit from exploitation of important information not available to the public" (Werhane, 1989, p. 841); (2) for economic aims, as "when truthfulness is not easy verifiable, restrictions on trading by insiders may be needed to preserve the integrity of information embodied in prices” (Benabou \& Laroque, 1992, p. 921).

Finally, in relation to the market studies under letter (d), it is necessary to underline the considerable extent of the economic and macroeconomic analyses, which are widely concentrated on the effects on the financial system of "sharp practices" (Rider, Alexander, \& Linklater, 2007).

The studies on the subject deal mainly with issues related to the stability of financial markets (Anderson, 2018) and their efficiency (Finnerty, 1976; Friedman, 1991; Sloman, 2006), which are generally disturbed by asymmetries (Allen \& Gorton, 1992) of both information and expectations (Harrison \& Kreps, 1978).

As for the national literature, in Italy, the subject of privileged information has been treated with particular attention by the legal doctrine (Alessandri, 2017; Bartalena, 1989; Benedettelli \& Lamandini, 2016; Capriglione, 2004; Macrì, 2010; Portale \& Cetra, 2017; Sgubbi, 2008), first of all because of the need—which emerged at the end of the last century - to provide the legal system with new legislation that was as appropriate as possible to the confined and only partially mature (at least at that time) Italian financial context.

Secondly, the interest has been solicited, on the one hand, by the important sanctions-administrative and criminal - related to the abuse of the privileged information and, on the other hand, by the problems concerning the exact qualification of the cases as legally relevant and punishable.

The study of the issue by the Italian business and accounting doctrines was rather less direct and specific, the national scholars being more interested in the different (but linked) problems concerning false accounting (Cavazzoni, 2004; Comoli, 2002; Superti Furga, 1996; Zigiotti, 2000) and false social communications (Paolini, 2007).

\title{
The Research Methodology
}

\section{Introduction}

The present research is based on a mixed empirical-qualitative method and aims to prove the thesis of a connection between financial statements and privileged information. To that end, the empirical survey focused on two areas: the data published by the Italian Stock Exchange and the cases decided by the Italian Court of Cassation. 
In particular, based on the empirical analysis, the price-sensitive information has been divided into different classes characterized by an acceptable degree of homogeneity; among them, those potentially able to produce economic effects on financial statements have been selected.

The incidence of the latter is around $40 \%$, and this research has considered this percentage sufficient to judge the relationship with financial statements as not marginal. The present study also found evidence of the existence of the aforementioned relationship in the judgments of the Italian Court of Cassation concerning financial cases in which information was intentionally kept confidential, even through the use of opaque or false financial statements.

Among the main limitations of the present study, it is important to stress, first of all, that the empirical survey does not allow us to make judgments on the level of information compliance. In particular, it is not possible to estimate whether the virtuous cases are statistically more numerous than the pathological ones. In this regard, the term "virtuous" refers to cases in which the economic effects of the transactions underlying the privileged information are adequately represented in the financial statements, while the term "pathological" refers to cases in which the accounting representation, even if feasible and obligatory, is intentionally omitted or altered according to abusive policies.

Secondly, although the analysis is inclusive of the entire population, it is limited to a short period of time, and it would be necessary to verify the significance of the conclusions reached through a set of data with a greater temporal extension and through the deepening of the European Union case-law, which is here not examined. ${ }^{3}$

\section{Hypothesis}

First of all, it is important to note that listed issuers have an open nature (Mancini, Paciello, Santoro, \& Valensise, 2016) ${ }^{4}$ and must therefore comply with enhanced informative obligations (Di Cataldo \& Sanfilippo, 2008; Quagli, 2004; 2013) which are provided for both by company law and market law. ${ }^{5}$ As a result, a complex system of public reporting has been established, consisting of (a) recurring information, mainly including the annual and half-yearly ${ }^{6}$ financial reports, the annual and consolidated financial statements, and the management reports; and (b) subsidiary and eventual disclosures, to be produced when events occur that (i) have not been included in the communications under letter (a) and (ii) are price-sensitive, i.e., able to affect the prices of the financial markets.

The so-called privileged information falls within the category under letter (b), and its notion is contained in Art. 181 of the Italian Consolidated Law on Finance, pursuant to which,

[...] for privileged information we mean information of a precise nature that has not been made public, directly or indirectly concerning one or more issuers of financial instruments or one or more financial instruments, which, if made public, could have a significant influence on prices of these financial instruments. [...] Information is considered to be of a precise nature if: (a) it refers to a set of circumstances that exists or that can reasonably be expected to come into existence

\footnotetext{
${ }^{3}$ For example, see the judgments of the European Court of Justice: lawsuits C-524/15, C-537/16, C-596/16, and C-597/16 about market abuse (ne bis in idem); lawsuit C-537/16 on market manipulation; lawsuit C-19/11 on the timeliness of the publication of privileged information.

4 “[...] the financial statements of the open companies [...] are, on the other hand, prepared according to the IAS/IFRS principles, which explicitly assign central importance (and, in fact, exclusive) to the disclosure function” (Mancini et al., 2016, p. 211).

5 The Civil Code, Legislative Decree 58/1998, the Regulations of Consob, the Regulations of the Italian Stock Exchange.

${ }^{6}$ Legislative Decree No. 25 of February 15, 2016, implementing Directive 2013/50/EU, has repealed the obligation to publish quarterly financial reports.
} 
or to an event that has occurred or that can reasonably be expected to occur; (b) it is specific enough to allow conclusions to be drawn on the possible effect of the set of circumstances or events referred to in point (a) on the prices of the financial instruments. For information that, if made public, could significantly affect the prices of financial instruments we mean information that a reasonable investor would presumably use as one of the elements on which to base his investment decisions. [...] (Legislative Decree 24 February 1998, No. 58)

Although the normative definition is particularly analytical, the exact identification of the notion of “privileged information” tends to be, in concrete cases, a mere "general clause” (D’Attorre, 2007, p. 304), which always requires a subjective assessment of complex implementation, especially to establish from a predictive point of view whether (a) the unpublished events or circumstances are able to influence market quotations and (b) this influence can be considered significant, given that, in the absence of this condition, the obligation to communicate the information does not exist.

As is known, the opportunity of a regulatory system that imposes the disclosure of privileged information is not unanimously shared. According to some scholars (Madhavan, 1996), ${ }^{7}$ especially the Anglo-Saxon ones, the obligation is, in some cases, difficult to respect in consideration of the subjectivity of the aforementioned preventive assessment; in other cases, it is ineffective, given the presence in the securities markets of irrational components (Bebczuc, 2003; D’Alessandro, 2014; Parisi \& Smith, 2005; Varvouzou, 2013) that prevent prices from perfectly reflecting the information available.

On the basis of these premises, the paper proposes the existence of a relationship, not always evident, between privileged information and financial statements. In particular, the study wants to show how, not infrequently, the information becomes or remains privileged precisely because it is not adequately represented in financial statements (i.e., in none of its components, balance sheet, statement of profit or loss, statement of changes in equity, statement of cash flows, and notes). ${ }^{8}$

As regards the procedure followed to demonstrate the aforementioned thesis, the paper uses two main classifications.

The first classification consists of distinguishing between:

(a) information timing and;

(b) information content.

In relation to the profile under letter (a), if the information is known after the publication of the financial statements, it requires ad hoc and timely communication that can reach the market at a time useful for investment decisions (Strampelli, 2015).

Concerning the profile under letter (b), i.e., the content of the information, it is necessary to further distinguish between $\left(b_{1}\right)$ information that can be shown in the financial statements as they are quantifiable and $\left(\mathrm{b}_{2}\right)$ non-measurable information that at most can be presented in the notes of financial statements in a descriptive and non-accounting form.

Based on these distinctions, the second classification divides the privileged information into two Groups:

\footnotetext{
7 "Many recommendations for reforming securities markets are predicated on the belief that providing information on order flow and other market variables to traders (i.e., increasing market transparency) will increase liquidity and improve price efficiency. This paper demonstrates that market transparency can actually increase price volatility and lower market liquidity. This occurs even though transparency increases the precision of traders' predictions about the asset's value” (Madhavan, 1996, p. 255).

8 According to IAS 1-Presentations of Financial Statements: "Notes contain information in addition to that presented in the statement of financial position, statement(s) of profit or loss and other comprehensive income, statement on changes in equity and statement of cash flows. Notes provide narrative descriptions or disaggregations of items presented in those statements and information about items that do not qualify for recognition in those statement”.
} 
- Group I consisting of privileged information that cannot be represented in financial statements, as it is not known or not quantifiable;

- Group II consisting of privileged information that can be represented in financial statements, in as much as it is known and susceptible to numerical expression.

For the formation of the Groups I and II, the research is based on the hypothesis that some information is of an eminently descriptive nature. This information can actually produce economic effects, but its inclusion in the financial statements is hindered by its difficult—or sometimes impossible—quantification. In this case the information belongs to the Group I.

On the contrary, other information is related to transactions that directly affect the company's capital and income. This information is not only price-sensitive but also often quantifiable in its economic effects. In fact, this information generally concerns operations that: a) are suitable for absorbing economic resources; b) involve a preliminary estimate of the expected results, as well as of the consequent financial commitments; and c) require a planning activity that is not only useful but also necessary (Potito, 2016). In this case the information belongs to the Group II.

The hypothesis that there is information with economic effects that can be quantified in the financial statements is formulated on the basis of the accounting rules set by the IAS/IFRS standards concerning, for example, the potential liabilities emerging during restructuring operations (see below, IAS 37) or in business combinations, ${ }^{9}$ and, more generally, the provision funds to be set up in the presence of presumed costs.

The same hypothesis is also confirmed by the legal decisions concerning various cases of investors damaged by violation of accounting rules, such as the failure to allocate risk funds in the presence of takeovers, ${ }^{10}$ or of operations on shares. ${ }^{11}$

In certain circumstances, the need for the provision funds, in particular for the risk of losing a lawsuit, has emerged precisely as a consequence of the consolidated case-law decisions, as in the case of damage caused to a minority by the failure to launch a mandatory offer, in the presence of a takeover. ${ }^{12}$

\section{The Results of the Empirical Research on the Italian Stock Exchange}

In order to establish whether the privileged information belongs to the first or the second group, this research focused on the price-sensitive communications published during the course of a calendar month ${ }^{13}$ by all the companies listed on the Italian Stock Exchange, ${ }^{14}$ for a total of almost 700 observations.

The grouping of the information according to its content has led to the identification of 12 relatively homogeneous classes (see Table 1).

\footnotetext{
${ }^{9}$ See IFRS 3-Business Combinations: "The acquirer shall disclose information that enables users of its financial statements to evaluate the nature and financial effect of a business combination that occurs either: (a) during the current reporting period; or (b) after the end of the reporting period but before the financial statements are authorized for issue".

${ }^{10}$ For example, see the case Cirio for the failure to allocate the provision for risks related to the commitment of a tender offer, Criminal Cassation, 1/30/2018, No. 4400.

11 Appeals Court, Bologna, Division III, 3/3/2015.

12 See in particular the case of Sai's ascent to Fondiaria Assicurazioni, which ended in 2002 with the merger and the establishment of Fonsai. On this point, the first civil division of the Italian Court of Cassation (20560/15), ruling in favor of minority shareholders for failure to launch the takeover bid, led Fonsai to allocate appropriate provisions for the risk of succumbing in court.

13 The survey covers the period 6/1/2018-6/25/2018.

${ }^{14}$ Source: Italian Stock Exchange-Documents—Price sensitive information.
} 
Table 1

\begin{tabular}{lll}
\multicolumn{2}{l}{ Classes of Privileged Information } & Incidence (\%) \\
\hline Class number & Information class & 24 \\
\hline 1 & Internal dealing & 14 \\
2 & Transactions on own shares & 13 \\
3 & Communications and press releases & 11 \\
4 & Notices of publication and publication of corporate documentation & 9 \\
5 & Core business operations & 8 \\
6 & Securities transactions & 7 \\
7 & Notices of calling and of resolutions of shareholders' meeting & 4 \\
8 & Takeovers & 4 \\
9 & Corporate bodies & 3 \\
10 & Mergers, demergers, and acquisitions & 2 \\
11 & Operations on the share capital & 1 \\
\end{tabular}

Source: own elaboration.

The contents of the classes are summarized in Table 2.

Table 2

Contents of the Classes of Privileged Information

\begin{tabular}{|c|c|}
\hline Class & Content \\
\hline Internal dealing & $\begin{array}{l}\text { Transactions on shares of the issuer carried out by "relevant parties", } 15 \\
\text { i.e., parties belonging to the company's bodies or apical staff, such as } \\
\text { directors, auditors, and top managers. }\end{array}$ \\
\hline Transactions on own shares & $\begin{array}{l}\text { Transactions involving the purchase and sale of own shares carried out } \\
\text { by the issuers. }\end{array}$ \\
\hline & $\begin{array}{l}\text { Information on the status of the issuer (rating, solvency, sustainability, } \\
\text { listing, changes in the level of indebtedness); various contractual }\end{array}$ \\
\hline Communications and press releases & $\begin{array}{l}\text { information (shareholders' agreements, expressions of interest, stock } \\
\text { option plans, incentive plans); information on the capital structure } \\
\text { (withdrawals, ownership restructuring). }{ }^{16}\end{array}$ \\
\hline $\begin{array}{l}\text { Notices of publication and publication of corporate } \\
\text { documentation }\end{array}$ & $\begin{array}{l}\text { Various publications concerning the company's activity (achievement } \\
\text { of revenue targets, statutory changes, letters of intent, declarations of } \\
\text { independence of directors and auditors, changes in the financial } \\
\text { calendar, approval and deposit of the financial statements). }{ }^{17}\end{array}$ \\
\hline Core business operations & $\begin{array}{l}\text { Notices concerning industrial and commercial transactions of } \\
\text { particular importance (acquisition of job orders, significant } \\
\text { investments in production, achievement of production or distribution } \\
\text { agreements, joint venture agreements, etc.). }\end{array}$ \\
\hline
\end{tabular}

15 The subjects who hold relevant positions are identified by Art. 114, c. 7, of the Italian Consolidate Law on Finance and by art. 152-sexies of the Issuers' Regulation No. 11971 of 1999.

${ }^{16}$ The class presents rather heterogeneous content because of the high number of topics included in it; however, it can be considered sufficiently unitary based on the nature of the information it groups; this information, indeed, is mainly qualitative and, above all, it is able to affect (also in pejus) the issuer's image. It should be noted that, in general, information is published with a thematic title that allows the immediate identification of the content; on the contrary, information with negative impact is published under the generic title of "press release”, and it always refers to critical issues of the business (shareholders' complaints, technical and production stops, wiretapping, reliefs of the supervisory board, postponements of financial statements, rumors and related denials).

17 The degree of homogeneity of this class is lower than that of the previous ones; the class is composed of different types of corporate information grouped into a single set due to their predominantly descriptive nature and due to the lower price-sensitive impact that, at least abstractly, they seem to possess. 
(Table 2 to be continued)

Securities transactions

Notices of calling and of resolutions of shareholders' meeting

Takeovers

Corporate bodies

Mergers, demergers, and acquisitions

Operations on the share capital

Corrigenda
Information relating to transactions in securities (bond issuance, bond conversions, securitization, warrants, coupon and futures transactions, payment of interest and dividends, etc.).

Notices of calling of shareholders' meetings and information regarding the resolutions passed by the shareholders' meetings, including the approval of the financial statements.

Information regarding takeover bids, subject to the prior control of Consob $^{18}$.

Notices concerning the appointment, revocation, and resignation of members of the corporate bodies.

Information regarding mergers, demergers, and acquisitions.

Mostly capital increase operations.

Corrections of errors in already published notices.

Source: own elaboration.

The classes of greatest incidence are those concerning the information on internal dealing operations and purchase of own shares, which, considered together, represent more than one-third of the population.

In this regard, it is significant to interpret the relative weight of the classes under examination by adding together the two categories of underlying transactions, since, although technically distinct, they share an emblematic connection with the issuer's organs and apical subjects: In fact, in the case of internal dealing operations, the apical subjects are buyers of the shares of the issuer, and in those of purchase of own shares, the same subjects contribute to the implementation of the operation by formulating the proposal (the directors), by granting the authorization (the shareholders' meeting), and by giving it execution (the directors, based on the authorization obtained).

Therefore, it can be inferred from the data collected that a large part of the price-sensitive information made public is related to transactions that can be substantially controlled by the issuer: The issuer being the holder of the power to implement these transactions, even unilaterally, it is able to carry them out for the sole purpose of soliciting the investors' confidence and their interest toward the company and its securities.

On the contrary, and with the exception of the mainly descriptive categories under 3, 4, and 7 (see Table 1), the other classes of information refer to transactions not fully governed by the issuer, being subject to negotiation with third parties (mainly other companies, investors, or social partners).

Finally, according to the hypotheses illustrated in the previous section the distribution of the 12 classes between Groups I and II (Table 3) is based on whether the information can be expressed in numerical and quantitative form and its economic effects can be represented in financial statements.

Given that the information in Group II is able to be recorded in accounts (Bruno, 2001), it is necessary to reconstruct the actual role of the financial statements in the use or abuse of privileged information by the issuers and their subsidiaries.

With regard to this role, it is important to remember that the obligatory means of communicating privileged information are not - under the existing law - the financial statements but an ad hoc communication to be made by means capable of reaching a wide audience. This is clearly due to the need for the privileged information to have a special and dedicated emphasis, in such a way as to be immediately known by the market.

\footnotetext{
${ }^{18}$ National Commission for Companies and the Stock Exchanged.
} 
Table 3

Not Quantitative and Quantitative Price Sensitive Information

\begin{tabular}{|c|c|c|c|}
\hline $\begin{array}{l}\text { Group I } \\
\text { Not quantitative price sensitive information }\end{array}$ & $\%$ & $\begin{array}{l}\text { Group II } \\
\text { Quantitative price sensitive information }\end{array}$ & $\%$ \\
\hline Internal dealing & 24 & Transactions on own shares & 14 \\
\hline Communications and press releases & 13 & Core business operations & 9 \\
\hline $\begin{array}{l}\text { Notices of publication and publication of corporate } \\
\text { documentation }\end{array}$ & 11 & Securities transactions & 8 \\
\hline $\begin{array}{l}\text { Notices of calling and of resolutions of shareholders' } \\
\text { meeting }\end{array}$ & 7 & Takeovers & 4 \\
\hline Corporate bodies & 4 & Mergers, demergers, and acquisitions & 3 \\
\hline Corrigenda & 1 & Operations on the share capital & 2 \\
\hline Total & 60 & Total & 40 \\
\hline
\end{tabular}

Source: own elaboration.

However, this does not exclude (see ultra Italian Court of Cassation), but rather makes it less evident, that financial statements often perform an effective function in the management of privileged information, being able to contribute, if regular, to its proper disclosure, or, vice versa, to concur, if irregular, with its illegal concealment: In the first case, the financial statements exercise their ordinary task as documents useful for the disclosure of information relevant to the market; in the second case, on the contrary, the financial statements are subject to a distorted and pathological use for the implementation of policies aimed at the abuse of the privileged information by those who have the information in advance thanks to their top position (public subjects, subjects internal or external to the issuer).

On this basis, the functions that the financial statements can assume with respect to the privileged information of Group II can be summarized in two types, which are illustrated in the following sections: the physiological function in the use of privileged information and the pathological function in the abuse of privileged information.

\section{The Results of the Case-Law Survey}

The case-law survey considers some decisions of the Italian Court of Cassation that are expressive of the relationships that may exist between financial statements and privileged information and that are representative of the pathological links that occur in the presence of opaque behavior towards the markets.

A first significant and complex case is represented by the Court of Cassation ruling, 3rd Civil Division, of 3/7/2014, No. 15224, with which the Court has reunited and rejected the appeals presented by a series of banks against sentence No. 1855/2007 of the Appeals Court of Milan.

In particular, the trial started with the writ of summons with which the plaintiffs called before the Court of Milan the companies Cariplo and Sanpaolo IMI (later merged into Intesa Sanpaolo), Banca Carige, Cassa di Risparmio of Turin (then UniCredit Banca), Credito Italiano, Banca di Roma, and Centrobanca to hear them sentenced to pay compensation for damages, patrimonial and not, suffered as a result of the purchase of shares in the subsequently bankrupt company SCI.

To demonstrate the responsibility of the defendant credit institutions, the plaintiffs pointed out that the same institutions were all components (with the exception of Centrobanca) of a restricted committee established for the rehabilitation of the SCI, which was seriously affected by the crisis in real estate. 
These institutions, after having converted their large loans into shares of the debtor company, had put the shares themselves up for sale, while the press had not leaked news of the SCI's crisis situation; on the contrary, the press had suggested an apparent improvement of the SCI's economic data and the possibility of a takeover bid on the company's shares (news which later proved to be unfounded).

At the same time, the banks, through the sale of the SCI shares in their possession, had reduced their overall shareholding in the company from the initial $78.1 \%$ to $14.1 \%$. The plaintiffs, in turn, had been induced to purchase the same shares, a total of 20,850,000. The securities had then gradually lost value until the SCI's declaration of bankruptcy.

The purchasers of the shares acted in court, requesting compensation for damages and, alternatively, the cancellation of the deeds of purchase of the shares and the conviction of the banks to the return of the price.

With decision No. 2193/2004, the Court of First Instance considered the objections partially founded and ordered the defendant banks to pay compensation in solidarity.

After the proposition of the principal appeals from the San Paolo Bank and of the incidental appeals from the other banks, to which the plaintiffs in the first degree resisted, the Appeals Court of Milan, with decision No. 1855/2007, confirmed the judgment of the Court of First Instance.

With subsequent acts, the banks have lodged appeals to the Court of Cassation.

The Court of Cassation observed that,

In the abstract, it could be objected, if anything, that privileged information may constitute a possible insider trading tool only when it concerns the behavior and decisions of others; not when [the privileged information] exclusively involves the [company's] own behavior, like in the case of the decision of the banks to close the road to any alternative solution to liquidation. However, [...] in this case it is not a question of information concerning exclusively one's own conduct, but of concurrent information with that pertaining to the objective economic situation of SCI; therefore there is actually an information imbalance with respect to the public of investors [...]. The conclusion of the Appeals Court regarding the existence of a causal link between the large and accelerated disinvestment of the SCI securities by the shareholder banks (over twenty million shares in two to three months) and the concomitant purchases by investors in unfavorable conditions is therefore widely and logically motivated. (3/7/2014, No. 15224)

The case described represents emblematically the role played by the financial statements in the concealment of the serious crisis situation the company was in: Not only did the financial statements not reveal the company's predicament, but they also showed a false improvement of data.

If the failure had been made sufficiently clear through the financial statements, the public of savers would not have been induced to make massive purchases of securities, nor would it have been possible for the banks to abuse the information in their possession, given that the same information, as clearly visible in the financial statements, would not have remained confidential.

In a different case, which is interesting because the appeal in the civil Court of Cassation was proposed by Consob and not against Consob, the same Court, rejecting the appeal, noted the unavoidable subjectivity of the values of the financial statements and considered that, in the situation examined, it was not possible to formulate a net judgment of falsity of the price-sensitive information given to the market.

Specifically, the problem concerns the statements made by UniCredit Banca D'Impresa with regard to the amount of losses—declared to be equal to one billion Euros—suffered in 2007 by customers of the banking group, due to transactions in derivative financial instruments. 
The same amount was publicly contested by ADUSBEF ${ }^{19}$, which estimated it at four to five billion Euros.

Following a complaint by UniCredit, in which it was confirmed that the amount of the mark-to-market was approximately one billion Euros, Consob initiated proceedings for violation of Art. 187 of the Italian Consolidate Law on Finance against ADUSBEF and imposed the related sanctions, considering that the statements made by the same ADUSBEF were false and misleading, and such as to negatively affect the prices of UniCredit's securities.

With decision No. 4/2010, the Appeals Court of Perugia, however, annulled the sanctioning measure (which ADUSBEF had opposed), considering, among other things, that,

It could not be claimed that the statements made had provided "false” and "misleading” assessment elements for users of the financial market, both because the attention of any interested parties was raised to a serious and real problem so as to allow them to carry out choices with greater awareness, and because it was evident that for the users of the market it was not the numerical expression of the phenomenon ( 4 or 5 billion or even 1 billion) that was important but its existence. (No. 4/2010)

Against the decision of the Appeals Court of Perugia, Consob presented an appeal to the Court of Cassation, which was rejected on the basis, inter alia, of the consideration that,

To calculate the mark to market (not of a single contract, but) of an entire derivatives portfolio requires the use of mathematical and financial models of discounting, together with the adoption of methodological choices that have an inevitable rate of technical questionability. It does not seem seriously doubtful, therefore, that a judgment in this regard cannot be subjected to the clear alternative between true and false, but is the expression of a personal appreciation, of an evaluative nature, deriving from the method of calculation used. (No. 9644/2016)

In this situation, therefore, the notion of falsehood was valued not in the abstract but in relation to the peculiar complexity of the case in question, which was particularly high, as it concerned the fair value measurements of derivative financial instruments.

\section{The Physiological Function of the Financial Statements in the Use of Privileged Information}

In the cases of physiological function, and of "good faith” (Demartini, 2004; Santesso \& Sòstero, 2016), the financial statements fully reflect, in their numerical expressions, the facts underlying the privileged information that influences the accounting results.

It should be noted that, in these cases, the financial statements do not replace the obligation to publish the privileged information through the channels required by law but integrate the information, making it as effective as possible, through its transformation into quantitative data; in other words, financial statements express through their own results the economic effects of the facts subject to disclosure.

The situations in which the events underlying the privileged information are represented by uncertain onerous phenomena (Onida, 1974, p. 85; Zappa, 1950, p. 481) are particularly emblematic. These situations concern events from which it is probable that costs for the issuer or its subsidiaries arise, given that, on the one hand, the publication of the information alerts investors and conditions their actions and, on the other hand, the financial statements can offer the measure or order of magnitude of the effects that the aforementioned events will generate on the income, capital, and cash flow of the issuer.

\footnotetext{
19 Banking and Financial Services Users Defense Association.
} 
In these cases, the financial statements perform their maximum explanatory function, since they not only complete the investors' judgment of the attractiveness of the securities but also enable the privileged information to act on market prices with greater quantitative precision.

The integrative function of the financial statements is evidently less effective when the events are not measurable (Group I). However, even in these situations, the privileged information could be represented in the notes to the financial statements in a descriptive form which in any case is useful to investors.

\section{The Pathological Function of the Financial Statements in the Abuse of Privileged Information}

The pathological cases (Migliaccio, 2012; Sannino \& Tartaglia Polcini, 2014) here in question are those in which the financial statements are consciously used for anti-juridical behavior (Benussi, 2016).

In these particular cases, the effects of the privileged information, even if measurable, are omitted in the financial statements.

Given that the privileged information is price-sensitive (otherwise, there would be no obligation to publish it), it is able to significantly influence market prices. Therefore, it is rather unlikely that the facts underlying the privileged information are completely unforeseeable, unknown, and unquantifiable, so as not to be in any way represented in the financial statements.

In these cases, therefore, the financial statements perform a pathological function and violate their own ordinary and mandatory tasks, since the wide space of subjectivity that the IAS/IFRS principles typically grant is used instrumentally to avoid expressing what could instead be represented, albeit by way of conjecture.

In this regard, by reconsidering, for example, the abovementioned onerous cases, it should be noted that the principles of the Italian civil code are designed to represent a realized income, while the IAS/IFRS standards are oriented towards a potential income, which can also include estimated and unrealized positive elements. However, it must be remembered that admitting potential revenues or excluding the recognition of potential liabilities, as expected by the IAS/IFRS, does not mean authorizing the omission of presumed costs; on the contrary, these are perfectly compatible with the notion of potential income, provided there are adequate conditions of measurability and probability. ${ }^{20}$

On this point, it is useful to recall the dictates of IAS 37, according to which it is true that no recognition should be made where the liabilities are only potential. However, the amplitude of this rule, only apparently undefined, is circumscribed through the assignment to the term "potential" of a specific content, which is useful to delimit precisely the cases in which it is applicable.

In fact, we can define "potentials" and therefore not record all eventual liabilities whose occurrence is subject to uncertain future events not controllable by the issuer, as well as current and known liabilities, whose extinction is expected not to lead to consumption of economic resources, or whose size cannot be measured with sufficient reliability.

However, except for these cases, with respect to which there is almost absolute uncertainty, there are all the situations in which the liabilities are realistically sure and measurable; these eventualities must thus be

\footnotetext{
${ }^{20}$ Pursuant to IAS 37-Provisions, Contingent Liabilities and Contingent Assets: “A provision shall be recognized when: (a) an entity has a present obligation (legal or constructive) as a result of a past event; (b) it is probable that an outflow of resources embodying economic benefits will be required to settle the obligation; and (c) a reliable estimate can be made of the amount of the obligation. If these conditions are not met, no provision shall be recognized”.
} 
recorded, for example through appropriate provisioning funds.

In this regard, many of the operations under examination belonging to Group II may correspond to the "restructuring",21 cases expressly mentioned by IAS 37 as typical examples of transactions likely to generate provisions.

The considerations made for the negative components of income are also applicable to the positive ones: The assets that are only potential cannot be recorded unless events occur that make the achievement of revenues virtually certain; in this case, the recording of positive components is appropriate. ${ }^{22}$

On this basis, it can be concluded that the hypothesis of the utilization of financial statements—alone or in combination with other manipulations-for the commission of information abuses against investors may occur in two cases: (a) omission or underestimation of potential costs and overvaluation of potential revenues, which encourage inappropriate investments, or (b) omission or underestimation of potential revenues and overvaluation of potential costs, which instead discourage profitable investments.

In addition to the cases described above, in which the privileged information is published pursuant to Art. 114 of the Italian Consolidate Law on Finance but is omitted in the financial statements, there is a further state, even more offensive, in which the financial statements alter, with active behavior, the representation of reality, making privileged the information that otherwise would not be such, were it represented in the accounts, according to the true and fair view principle.

The emblematic cases in this regard are those in which the privileged information concerns the issuer's state of crisis and is known to the company's apical subjects but is concealed by altering the data of financial statements (Di Carlo \& Bisogno, 2012; Poddighe \& Madonna, 2006) or, more frequently, with the help of false financial statements that obscure losses or exhibit nonexistent profits.

In fact, it is evident that crisis situations do not appear suddenly, like unexpected or unforeseeable events, but, on the contrary, they reveal themselves through progressively increasing symptoms, of which financial statements are among the most effective representation tools.

Thus, the concealment of the crisis corresponds exactly to the case in which the information, although not privileged in abstract-inasmuch as it is obliged to appear in the accounts-becomes privileged in practice due to the violation of the natural site-the published financial statements-from which it should emerge.

\section{Conclusions}

From the above considerations, some conclusions can be reached.

First of all, the centrality of the information function played by financial statements strongly emerges with respect to two subjects: (a) for listed issuers, who turn to a market that is imperfectly rational but vast and sensitive to all information that can affect the prices of the financial instruments, and (b) for investors, who need maximum transparency for their investment decisions.

In this regard, the financial statements can assume, towards the financial markets, not only a virtuous function of disseminating information useful for the formulation of informed investment decisions but also an

\footnotetext{
${ }^{21}$ Examples of restructuring, according to IAS 37, are: the sale or closure of a product line; the closure of factories or their transfer to other countries; change in management structures; significant reorganizations that have a relevant effect on the nature of the business and on its strategic orientation.

22 Note that IAS 37 excludes the recording of potential assets when they arise from unpredictable and unplanned operations. But, in most of the cases included in Group II the operations are precisely planned because they concern complex activities, typically with progressive training (OPA, mergers, demergers, acquisitions, restructuring, etc.).
} 
opposite and pathological function of concealment or abuse of privileged information.

Secondly, the empirical results of the survey referring to companies listed on the Italian Stock Exchange confirmed that almost $40 \%$ of the privileged information published regards unilateral and self-governed transactions, i.e., transactions that are under the control and the power of the issuers.

The widespread use of this category of operations can be justified by the desire to give the market precise guidelines, which are likely to support trading volumes, the prices of the securities, and their resistance through the demonstration of the credit that the company enjoys and the trust that the apical subjects have in it, so that the same trust can be transmitted to the market.

In this sense, the publication of price-sensitive information is not only mandatory but also functional to the strategies pursued by the issuer for soliciting savings.

Thirdly, some cases submitted to the Italian Court of Cassation confirm that the abuse of privileged information is often used instrumentally in financial statements as a means of disseminating untrue data or of concealing truthful data to maintain an information advantage to the detriment of the market.

Despite the conclusions reached here, this study is open to new discussions. A first point of debate could concern the analysis of data relating to financial markets other than Italy's.

To this end, it would be very useful to carry out an empirical survey on broader and more advanced financial markets, such as the American one.

From the comparison of the data referring to different financial markets, in fact, further elements of study could emerge, such as (a) the reasons for the information behaviors adopted by the listed companies, (b) the characteristics of the investors to whom the financial statements are addressed, or (c) the legal framework and the effectiveness of the laws in force.

Precisely with reference to the legal framework, which is not detailed in this survey, a further point of debate could emerge. It would in fact be useful to investigate whether the pathological relationships that are established between privileged information and financial statements are attributable to the illegal behavior of the issuers or caused by the inadequacy of the laws governing the financial markets and the preparation of the financial statements.

In this regard, it is likely that pathological relationships are caused by both, since, generally, illegal behaviors can exist because the laws are not able to fight them effectively or to prevent them from the beginning.

In this sense, this study could contribute to the search for new insights into the dynamics that do not always make financial information transparent and suited to the needs of investors.

\section{References}

Alessandri, A. (Ed.). (2017). Reati in materia economica. Torino: Giappichelli.

Ali, P. U., \& Gregoriou, G. N. (Eds.). (2009). Insider trading. Global developments and analysis. Boca Raton: CRC Press.

Allen, F., \& Gorton, G. (1992). Stock price manipulation, market microstructure and asymmetric information. European Economic Review, 36(2-3), 624-630. doi: 10.1016/0014-2921(92)90120-L

Allhoff, F., \& Vaidya, A. (2005). Business ethics. Professional ethics. London: Sage Publications.

Anderson, J. P. (2018). Insider trading. Law, ethics, and reform. New York: Cambridge University Press.

Austin, J. (2017). Insider trading and market manipulation. Investigating and prosecuting across borders. Cheltenham: Elgar.

Bagley, C. E. (2017). Managers and the legal environment. Strategies for business. Boston: Cengage.

Bailey, W., Li, H., Mao, C. X., \& Zhong, R. (2003). Regulation fair disclosure and earnings information: Market, analyst, and corporate responses. The Journal of Finance, 58(6), 2487-2514. doi: 10.1046/j.1540-6261.2003.00613.x 
Bainbridge, S. M. (Ed.). (2013). Research handbook on insider trading. Cheltenham: Edward Elgar.

Bartalena, A. (1989). L'abuso di informazioni privilegiate. Milano: Giuffrè.

Bebczuc, R. N. (2003). Asymmetric information in financial markets. Introduction and applications. Cambridge: Cambridge University Press.

Benabou, R., \& Laroque, G. (1992). Using privileged information to manipulate markets: Insiders, gurus, and credibility. The Quarterly Journal of Economics, 107(3), 921-958. doi: 10.2307/2118369

Benedettelli, M., \& Lamandini, M. (Eds.). (2016). Diritto societario europeo e internazionale. Milano: Wolters Kluwer.

Benussi, C. (2016). I nuovi delitti di false comunicazioni sociali e la rilevanza penale delle false valutazioni. In Diritto Penale Contemporaneo (pp. 1-64). Milan, Italy.

Boonin, D., \& Oddie, G. (2005). What's wrong? Applied ethicists and their critics. New York: Oxford University Press.

Bruno, S. (2001). L'azione per danni da informazione non corretta sul mercato finanziario: Diritto comune e legislazione speciale. Contratto e Impresa, 17(3), 1287-1344.

Capriglione, F. (2004). Diritto comunitario e tutela del risparmio. La nuova giurisprudenza civile commentata, 6, 664-676.

Caprio, G. (Ed.). (2013). Handbook of safeguarding global financial stability: Political, social, cultural, and economic theories and models. London: Elsevier.

Cavazzoni, G. (2004). Il falso in bilancio. Riflessioni sulle novità della legge di riforma. Torino: Giappichelli.

Comoli, M. (2002). Il falso in bilancio. Principi di ragioneria ed evoluzione del quadro normativo. Milano: Egea.

D’Alessandro, F. (2014). Regolatori del mercato, enforcement e sistema penale. Torino: Giappichelli.

D’Attorre, G. (2007). Il principio di eguaglianza tra soci nelle società per azioni. Milano: Giuffrè.

Davies, P., Hopt, K. J., Nowak, R., \& Van Solinge, G. (Eds.). (2013). Corporate boards in law and practice. A comparative analysis in Europe. Oxford: Oxford University Press.

Demartini, P. (2004). Informazione, imprese e mercati finanziari efficienti. Spunti di riflessione in una prospettiva multidisciplinare. Milano: FrancoAngeli.

Di Carlo, A., \& Bisogno, M. (Eds.). (2012). Crisi e risanamento d'impresa in una prospettiva internazionale. Analisi economica e strumenti giuridici. Milano: FrancoAngeli.

Di Cataldo, V., \& Sanfilippo, P. M. (2008). Le fonti private del diritto commerciale. Milano: Giuffrè.

Di Toro, P. (2012). Scalata azionaria e OPA “europea”. Le contese per la conquista del potere di governo nelle società quotate. Milano: Egea.

Easterbrook, F. H. (1981). Insider trading, secret agents, evidentiary privileges, and the production of Information. The Supreme Court Review, 1981, 309-365. doi: 10.1086/scr.1981.3109548

Finnerty, J. (1976). Insiders and market efficiency. The Journal of Finance, 31(4), 1141-1148. doi: 10.1111/j.1540-6261.1976.tb01965.x

Friedman, D. (1991). Privileged traders and asset market efficiency. A laboratory study. Santa Cruz: Dept. of Economics, University of California.

Friedrichs, D. O. (2009). Trusted criminals. White collar crime in contemporary society. Belmont: Cengage Learning.

Gaillard, E. (1992). Insider trading. The laws of Europe, the United States and Japan. Deventer: Kluwer.

Harrison, J. M., \& Kreps, D. M. (1978). Speculative investor behavior in a stock market with heterogeneous expectations. The Quarterly Journal of Economics, 92(2), 323-336. doi:10.2307/1884166

Leuz, G., \& Wüstenamm, J. (2003). The role of accounting in the German financial system. In CFS Working Paper, 2003/16 (pp. 1-51). doi: $10.2139 / \mathrm{ssrn} .427000$

Loke, A. F. (2006). From the fiduciary theory to information abuse: The changing fabric of insider trading law in the U.K., Australia and Singapore. The American Journal of Comparative Law, 54(1), 123-172. doi: 10.1093/ajcl/54.1.123

Macrì, E. (2010). Informazioni privilegiate e disclosure. Torino: Giappichelli.

Madhavan, A. (1996). Security prices and market transparency. Journal of Financial Intermediation, 5(3), 255-283. doi: 10.1006/jfin.1996.0015

Mancini, M., Paciello, A., Santoro, V., \& Valensise, P. (Eds.). (2016). Regole e mercato. Tomo I. Torino: Giappichelli.

Markham, J. W. (2002). A financial history of the United States. New York: M. E. Sharpe.

Migliaccio, G. (2012). Squilibri e crisi nelle determinazioni quantitative d'azienda. Il contributo della dottrina italiana. Milano: FrancoAngeli.

Onida, P. (1974). Il bilancio d'esercizio nelle imprese. Significato economico del bilancio. Problemi di valutazione. Milano: Giuffrè. 
Paolini, A. (Ed.). (2007). False comunicazioni sociali. Milano: Giuffrè.

Parisi, F., \& Smith, V. L. (Eds.). (2005). The law and economics of irrational behavior. Stanford: Stanford University Press.

Poddighe, F., \& Madonna, S. (Eds.). (2006). I modelli di previsione delle crisi aziendali: possibilità e limiti. Milano: Giuffrè.

Portale, G. B., \& Cetra, A. (2017). Acquisto di quote di fondo comune di investimento e situazioni di conflitto di interessi in una

SGR. Banca, Borsa e Titoli di credito, 5, 577-585.

Potito, L. (2016). Le operazioni straordinarie nell'economia delle imprese. Torino: Giappichelli.

Quagli, A. (2004). Comunicare il futuro. L'informativa economico-finanziaria di tipo previsionale delle società quotate italiane. Milano: FrancoAngeli.

Quagli, A. (2013). Bilancio di esercizio e principi contabili. Torino: Giappichelli.

Rider, B. A. K., Alexander, K., \& Linklater, L. (2007). Market abuse and insider dealing. Haywards Heath: Tottel Publishing.

Sannino, G., \& Tartaglia Polcini, P. (2014). I fini del bilancio nel modello IASB: Evoluzione o regresso? Analisi critica e confronto con la realtà dell'Europa Continentale. Torino: Giappichelli.

Santesso, E., \& Sòstero, U. (2016). I principi contabili per il bilancio d'esercizio. Analisi e interpretazione delle norme civilistiche. Milano: Egea.

Sekhar, R. C. (2002). Ethical choices in business. New Delhi: Response Book.

Sgubbi, F. (2008). Diritto penale del mercato finanziario. Padova: Cedam.

Sloman, J. (2006). Economics. Harlow: Pearson Education.

Stamp, M., \& Welsh, C. (1996). International insider dealing. London: Financial Times Law and Tax.

Strampelli, G. (2015). L'enforcement “pubblico” dell’informazione contabile tra strumenti di carattere preventivo e sanzioni reputazionali. Rivista delle Società, 4, 573-606.

Sunder, S. (1997). Theory of accounting and control. Cincinnati: South-Western Publishing.

Superti Furga, F. (1996). Funzioni qualificanti nell’attività di controllo del collegio sindacale. Rivista dei Dottori Commercialisti, 6, 985-993.

Tricker, B. (2015). Corporate governance. Principles, policies, and practices. Oxford: Oxford University Press.

Varvouzou, I. (2013). Capital market anomalies. Explained by human's irrationality. Hamburg: Anchor Academic Publishing.

Veil, R. (Ed.). (2017). European capital markets law. Oxford: Hart Publishing.

Werhane, P. H. (1989). The ethics of insider trading. Journal of Business Ethics, 8(11), 841-845. doi: 10.1007/BF00384525

Wüstemann, J. (2003). Disclosure regimes and corporate governance. Journal of Institutional and Theoretical Economics, 159(4), 717-726. doi: 10.1628/0932456032584595

Zappa, G. (1950). Il reddito di impresa. Milano: Giuffrè.

Zigiotti, E. (2000). Il falso in bilancio nei suoi fondamenti di ragioneria. Padova: Cedam. 